\title{
The effect of mitomycin-c in keloid fibroblast cultures
}

\author{
Ishandono Dachlan ${ }^{1 *}$ Teguh Aryandono ${ }^{2}$, Mae Sri Hartati Wahyuningsih ${ }^{3}$, Hardyanto \\ Soebono ${ }^{4}$, Yohanes Widodo Wirohadidjojo ${ }^{4}$ \\ ${ }^{1}$ Plastic and Reconstructive Surgery Division, Department of Surgery, Faculty of Medicine, \\ Universitas Gadjah Mada/Dr. Sardjito Hospital, Yogyakarta, Indonesia, ${ }^{2}$ Surgical Oncology \\ Division, Department of Surgery, Faculty of Medicine, Universitas Gadjah Mada/Dr. \\ Sardjito Hospital, Yogyakarta, Indonesia, ${ }^{3}$ Department of Pharmacology and Therapy, \\ Faculty of Medicine, Universitas Gadjah Mada, Yogyakarta, Indonesia, ${ }^{4}$ Department of \\ Dermatology and Venereology, Faculty of Medicine, Universitas Gadjah Mada/Dr. Sardjito \\ Hospital, Yogyakarta, Indonesia
}

DOI: http://dx.doi.org/10.19106/JMedSci004803201605

\section{ABSTRACT}

Keloid occurs due to hyperactivity of keloid fibroblast (KF) in proliferation, migration, collagen deposition, together with low rates of collagen degradation. These are under the responsibility of TGF- $\beta$. Mitomycin $C$ (MC) is used for treating keloid by a topical application during surgery at the level of $0.02 \%$ to $0.08 \%$. Unfortunately, the lowest effective level of $\mathrm{MC}$ for keloid has not been determined yet. We aimed to determine the lowest effective level of MC in the suppression of KF activities. Various levels of MC diluted in growth medium were administered on KF that were isolated from six patients. After 24 hours and 72 hours of incubation, cellular proliferation, collagen deposition, cellular migration and level of TGF- $\beta$, were analyzed. Application of $120 \mathrm{uM} \mathrm{MC}$ on KF culture for 24 hours could significantly reduce TGF- $\beta$ production from $1265.74 \pm 274.81$ $\mathrm{pg} / \mathrm{mL}$ to $265.17 \pm 12.20 \mathrm{pg} / \mathrm{mL}$; proliferation index from $100 \%$ to $84.01 \pm 12.91 \%$; inhibit cellular migration to $64.38 \pm 3.66 \%$; but reduce collagen depositions from $100 \%$ to only $91.13 \pm 10.19 \%$. The lowest $\mathrm{MC}$ level is on $30 \mathrm{uM}$ or equal with $0.001 \%$. In conclusion, the lowest level of MC can suppress the activities of KF is $0.001 \%$. Moreover, due to low activity in inhibiting collagen deposition, MC would be better as an adjuvant drug for keloid surgery.

\section{ABSTRAK}

Keloid timbul karena proliferasi, migrasi, dan sintesis kolagen oleh fibroblas keloid (FK) secara berlebihan diikuti dengan rendahnya degradasi kolagen. Semua itu terjadi karena pacuan TGF- $\beta$. Olesan mitomycin C (MC) 0,02\% sampai 0,08\% digunakan untuk mengobati dan mencegah kekambuhan keloid yang dioperasi. Sayangnya, dosis terendah yang masih efektif belum pernah diteliti. Penelitian ini bertujuan untuk menentukan kadar terendah MC yang masih efektif untuk mengobati keloid. MC dilarutkan dalam medium pertumbuhan dalam berbagai kadar dan diberikan pada biakan FK yang diisolasi dari material keloid enam orang pasien. Setelah inkubasi 24 jam dan 72 jam, proliferasi, migrasi, timbunan kolagen dan kadar TGF- $\beta$, dianalisis dan dibandingkan. Pemberian 120 uM MC pada biakan FK ternyata dapat menurunkan produksi TGF- $\beta$ dari 1265,74 \pm 
$274,81 \mathrm{pg} / \mathrm{mL}$ menjadi $265.17 \pm 12.20 \mathrm{pg} / \mathrm{mL}$; indek proliferasi dari $100 \%$ menjadi $84,01 \pm 12.91 \%$; menghambat migrasi sampai $64,38 \pm 3.66 \%$, tetapi daya hambat timbunan kolagen hanya dari $100 \%$ menjadi $91.13 \pm 10.19 \%$. Kadar MC terendah yang masih efektif adalah $30 \mathrm{uM}$ atau setara dengan $0.001 \%$. Kadar MC di bawah itu tidak lagi efektif. Kesimpulan, kadar MC terendah yang masih efektif sebesar 0,001\% dan karena daya hambat timbunan kolagen yang rendah, MC sebaiknya digabung dengan operasi keloid.

Keywords: keloid fibroblast - mitomycin-c - TGF- $\beta$ - deposition - proliferation

\section{INTRODUCTION}

Keloid is a fibroproliferative benign tumor that found only on human skin with characteristics in persistent overgrowth of fibrous tissues during wound healing leading to the formation of over scar tissues more than original wound size, and can invade surrounding normal tissue as a crab-claw of keloid lesion. ${ }^{1,2}$ This overgrowing is due to keloid fibroblast (KF) proliferation and producing collagen excessively ${ }^{3-5}$ together with low activity of extracellular matrix metalloproteinase (MMP). ${ }^{6,7} \mathrm{KF}$ also have a characteristic of mesenchymal stem cells and can migrate to surrounding normal tissues to produce enlargement of fibrous tissues. ${ }^{8}$ Moreover, one of various growth factors that have an important role in keloid behavior is transforming growth factor- $\beta$ (TGF- $\beta$ ). ${ }^{9}$ This growth factor can induce $\mathrm{Wnt} / \beta$-catenin signaling, ${ }^{10}$ and over-expression of $\mathrm{Wnt}$ is parallel with collagen deposition in both keloid tissues and $\mathrm{KF}$ culture. ${ }^{11,12} \mathrm{Wnt} / \beta$ catenin signaling pathway is not only responsible for collagen production but it also has an important role in inducing transformation of human dermal microvascular endothelial cells to become KF. ${ }^{12}$

Mitomycin-C (MC) is an anti-cancer commonly used for bladder cancer and others, including as the preventing agent for pterygium by topical application intraoperatively. ${ }^{13}$ Interestingly, the target of this agent is pterygial body fibroblasts that produce fibrotic tissues under stimulation of connective tissue growth factor (CTGF) initiated by TGF- $\beta .{ }^{14}$ Similar with it, MC is also used in keloid lesion by topical application intra-operatively to suppress KF activities. Talmi et $a l^{15}$ apply MC to the wound of keloid excision and resulting in the complete disappearance of keloid lesion. $\mathrm{MC}$ can prevent keloid recurrence up to $80 \%$ when applied topically to the base of shaveremoving keloid surgery. ${ }^{16}$ The side effects of topical application of $0.02 \% \mathrm{MC}$ (equal with $598 \mathrm{uM}$ ) among patients with pterygium is low, mild, and reversible. ${ }^{13}$ Application of MC intra-operatively is ranged from $0.02 \%$ to $0.08 \%$ (equal with $2393 \mathrm{uM}$ ), but whether $0.02 \%$ as the lowest effective level of MS is still unknown. In order to know the lowest level of MC in topical-application for keloid surgery, we reported the effect of various low level MC on KF culture, therefore, the best level of MC in keloid surgery may be determined.

\section{MATERIAL AND METHODS}

\section{Isolation and culture of $\mathrm{KF}$}

The core of keloid materials was obtained from six patients underwent keloid debulking surgery with informed concerns. About $2 \mathrm{~cm}^{3}$ of each material was thinly sliced into 2-3 $\mathrm{mm}^{3}$ pieces and cultured by explants method in Dulbecco's Modified Eagle's Medium 
(DMEM, Gibco®, USA) containing 10\% fetal bovine serum (FBS, Gibco®,USA) and $1 \%$ penicillin/streptomycin (Gibco®, USA) at $37^{\circ} \mathrm{C}$ and $5 \% \mathrm{CO} 2$. The spindle-shaped cells that outgrown from the explants then were subcultured until passage 4 .

\section{Experiments}

\section{Stock MC-preparation}

MC (molecular weight $=334.33$ ) was purchased from Biochem Pharmaceutical Industry Ltd., Mumbai, India under license from Kyowa Hakko Kogyo, Japan. After dissolving $10 \mathrm{mg} \mathrm{MC}$ in $25 \mathrm{~mL}$ sterile water $($ molarity $=1.1964 \mathrm{mM})$, further dilution with DMEM was performed until stock MC in the level of $600 \mathrm{uM}$. Referring to the findings of Wang et al., ${ }^{17}$ on human dermal fibroblasts, we began to treat KF with $120 \mathrm{uM} \mathrm{MC}$.

\section{Design and treatment}

All of the experiments were then conducted in the following scheme:

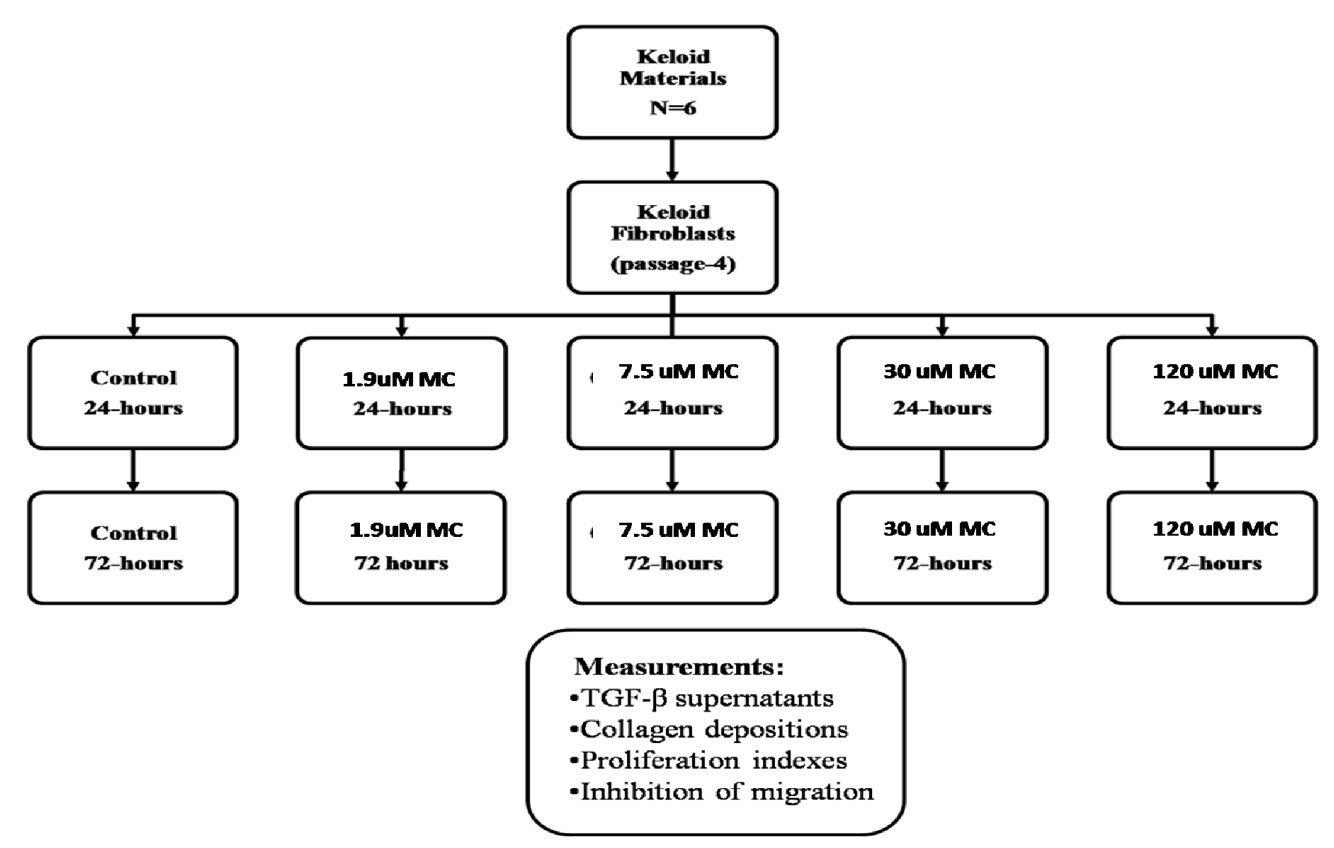

FIGURE 1. Preparation and measurement scheme

The experiment was carried out with $\mathrm{KF}$ reseeding in wells of $200 \mathrm{uL}$ cell suspension containing 103 cells $/ \mathrm{mL}$. After 24 hours of incubation to let cells attached on the bottom of wells, various treatments carried out in accordance with a written scheme on above. All of the procedures were in triplicate.

\section{Measurement of variables \\ Proliferation index}

Cellular viabilities were measured using MTT \{-(3-(4.5-dimethylthiazol-2-yl)-2.5diphenyltetrazolium bromide purchased from MP biomedical-France $\}$ assay and optical density (OD) of formazan blue produced by living cells and were determined using spectrometer at $570 \mathrm{~nm}$ of wavelength. All of the ODs from the control group was 
considered as $100 \%$ of the proliferation index, therefore, the proliferation index of various treated groups was counted as: (OD of treated group / OD of paired control) x $100 \%$.

\section{Ability to deposite collagen}

Collagen deposition was measured by insoluble collagen of Sirius red (purchased from Sigma-Aldrich, Steinheim, Germany) assay according to Taskiran et al., ${ }^{18}$ the OD Sirius red-bound collagen represented the amount of insoluble collagen and it was read using spectrometer at $570 \mathrm{~nm}$ of wavelength. The OD of the control group was considered as $100 \%$ ability to deposit collagen. The ability of various treated groups was counted as: (OD of treated group / OD of paired control) $\times 100$ $\%$.

\section{Inhibition of cellular migration}

Cellular migration assay was performed based on method Liang et al., ${ }^{19}$ briefly, after serum starvation, all bottom of wells were linearly scratched with the blunt tip of a $32 \mathrm{G}$ sterile needle through the center of the well bottom. After cultivation with various media and incubations, the cells were then stained with Meyer's Haematoxylin and microscopic photo images were taken using a Moticam-350 camera (China) in JPG format. Both blue color's pixels of fibroblasts along the scratch line and white color's pixels of empty space can be measured using Adobe-Photoshop. Migration rate was counted as: (blue color pixel of KF along the scratch line / total pixel along the scratch line ) $\times 100 \%$. Inhibition of migration of treated group was counted as migration rate of control minus migration rate of paired treated group.

\section{TGF- $\beta$ level}

The level of TGF- $\beta$ in the supernatant of various groups was measured using human TGF- $\beta 1$ ELISA kit purchased from Bender MedSystem (Burlingame, USA). The OD of each well was read using spectrometer at 570 $\mathrm{nm}$ of wavelength and the level of TGF- $\beta$ was counted using standard curve obtained from a correlation between various standardized TGF- $\beta$ with their OD.

\section{Statistics}

All data are presented as a mean \pm standard error. We used one -ay analysis of variance (ANOVA) followed by LSD to analyze the migration rate data and Friedman test followed by Wilcoxon as post hoc test to analyze the proliferation index and collagen deposition data. The level of statistical significance was accepted at $\mathrm{p}<0.05$.

\section{RESULTS}

Application of $120 \mathrm{uM} \mathrm{MC}$ on KF culture for 24 hours can reduce: TGF- $\beta$ production from: $1265.74 \pm 274.81 \mathrm{pg} / \mathrm{mL}$ to 265.17 $\pm 12.20 \mathrm{pg} / \mathrm{mL}$; collagen depositions from $100 \%$ to $91.13 \pm 10.19 \%$; proliferation index from $100 \%$ to $84.01 \pm 12.91 \%$; and inhibit cellular migration up to $64.38 \pm 3.66 \%$. The effect of diluted MC on KF culture both for 24 hours and 72 hours can be observed in the following FIGURES. 


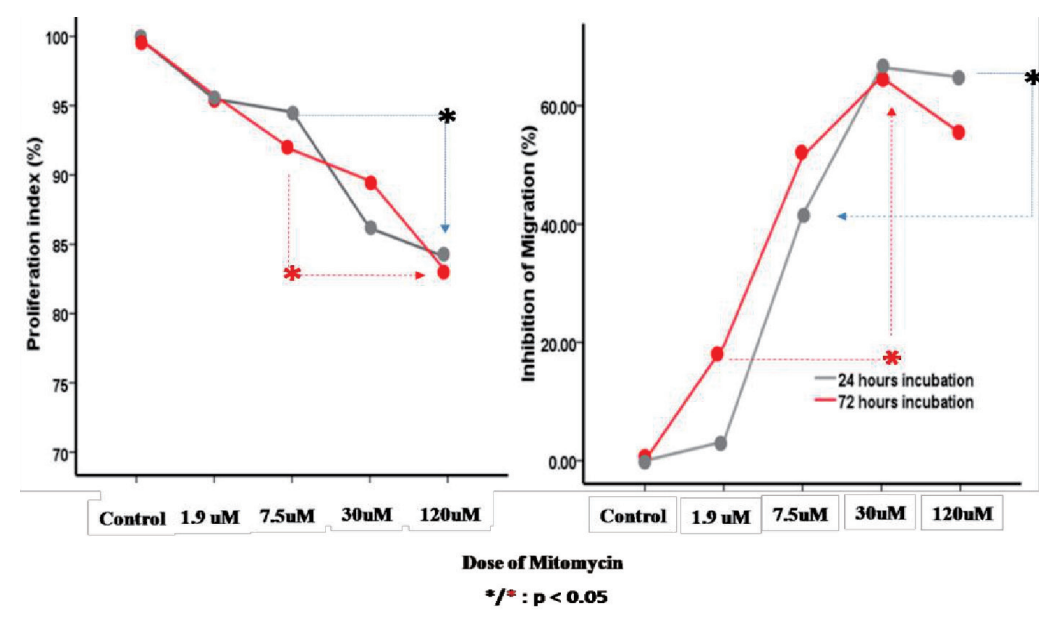

FIGURE 2. Effect of MC on proliferation and cellular migration

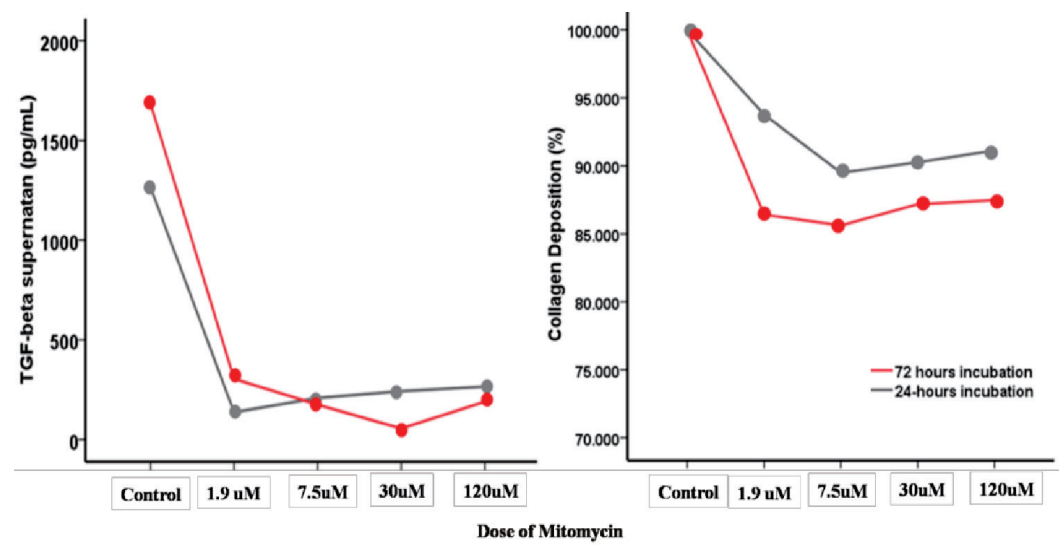

FIGURE 3. The effect of MC on TGF- $\beta$ and collagen deposition

\section{DISCUSSION}

Various keloid treatments, starting from surgery to intralesional corticosteroid and various anti-cancers such as fluorouracil,${ }^{20}$ bleomycin, ${ }^{21} \mathrm{MC},{ }^{15,16,22}$ or a combination of them have been performed. ${ }^{23} \mathrm{MC}$ has been chosen because it can inhibit normal skin fibroblast proliferation, induce fibroblast apoptosis, and regulate intracellular protein expression on mRNA level. ${ }^{17}$

Our results showed that $120 \mathrm{uM} \mathrm{MC}$ can inhibit proliferation and migration of $\mathrm{KF}$
FIGURE 1. This finding is important because continuously enlargement of keloid lesion is under responsible of high proliferation rate of $\mathrm{KF}^{3-5}$ and high migration ability to invade surrounding normal tissue. ${ }^{8}$ Application 120 $\mathrm{uM} \mathrm{MC}$ for 72 hours had no significantly different effect in proliferation index and inhibition of cellular migration than 24 hours. Dilution of $120 \mathrm{uM}$ MC into a quarter, oneeighth and so on indicated that significant different $(\mathrm{p}<0.05)$ in KF proliferation and migration was existed on $7.5 \mathrm{uM}$ and below, 
both 24 hours and 72 hours of administration. So, it can be concluded that lowest level of $\mathrm{MC}$ is on the level of $30 \mathrm{uM}$ or equal to 10.03 $\mathrm{ug} / \mathrm{mL}$ or equal to $0.001 \%$.

Regulation of KF protein expression by $120 \mathrm{uM}$ MC can be observed in FIGURE 2, as it was indicated by reducing the TGF- $\beta$ level and collagen deposition. Based on low inhibition of collagen deposition (about 10\% of 24 hours of incubation), it seemly indicated that $\mathrm{MC}$ as a single drug is not worthy to be used for treating keloid lesion otherwise repeated injections of MC must be given. Based on high inhibition of $\mathrm{MC}$ in cellular migration and cellular proliferation on above, it looked that $\mathrm{MC}$ administration just has prevention effect in keloid progression. It has been known that extensive enlargement of keloid lesions is due to KF proliferations, collagen depositions, and cellular migrations. ${ }^{3-5}$ In order to totally treat keloid lesions, we agree that MC must be combined with keloid surgery that removes the existing fibrous tissue material which richens by collagen bundles, such as previously reported by many authors. ${ }^{15,16,22,23}$ In this combination, unremoving $\mathrm{KF}$ and collagen bundles on the surface of debulking lesions of preexisting keloid can be prevented to grow and to be prevented to relapse. The significant different of collagen deposition between 72 hours and 24 hours of application (as it shown by red dot) showed that MC could stimulate collagen degradation as manifestation of MMP activation. Among KF, production of tissue inhibitor of metalloproteinase (TIMP)2 is high and MMP-2 is low. A study showed that application of IL- $\beta$ can convert this event to become increasing MMP-2 level together with decreasing TIMP-2 parallel with increasing collagen degradation. ${ }^{24} \mathrm{We}$ suspected that increasing collagen degradation in our experiment was due to $\mathrm{MC}$ regulate $\mathrm{KF}$ in interleukin- $\beta$ protein expression. A further research to clarify this hypothesis should be performed in the future.

So far, there is no any criterion for converting drug level obtained from cell culture to the equal dosage for human in clinical applications. Atashkina et $a .^{25}$ assume that so many variables must be considered before converting those drug's levels in the human body, for example: whether cultured cellular models exhibiting reliable, known and intact biochemical pathways and structural elements are same with keloid lesions. For these purposes, our experiment in two dimensions KF culture had limitation at least in structural elements where excessive collagen bundles before having treatments were not represented in our cells condition. This limitation may affect on effective drug's level that is lower than it should be in keloid lesion. Since there is no representative animal model for keloid study, a further study in three dimensions of organotypic keloid culture must be conducted, so the lowest effective level of MC can be determined. The comparison of 3 dimensions culture's weight and the monolayer culture's weight can be used to determine starting level of MC for further researches.

\section{CONCLUSION}

MC is just applicable in preventing recurrence of keloid after having keloid surgery. Moreover, the lowest effective level of $\mathrm{MC}$ is $30 \mathrm{uM}$ for a monolayer of KF culture or equal to $0.001 \%$ but it must be recalculated in the clinical application of keloid surgery and it depends on the estimation of residual fibrous tissues weight.

\section{ACKNOWLEDGEMENT}

Authors would like to thank Head of Department of Dermatology and Venereology, Faculty of Medicine, Universitas Gadjah 
Mada, for allowing me to work in cell culturing and technical measurement.

\section{REFERENCES}

1. Mrowietz U, Seifert O. Keloid scarring: new treatments ahead. Actas Dermosifiliogr 2009; 100 Suppl 2:75-83. http://dx.doi.org/10.1016/ S0001-7310(09)73382-4

2. Hunasgi S, Koneru A, Vanishree M, Shamala R. Keloid: A case report and review of pathophysiology and differences between keloid and hypertrophic scars. J Oral Maxillofac Pathol 2013; 17(1):116-20. http:// dx.doi.org/10.4103/0973-029X.110701

3. Chipev CC, Simman R, Hatch G, Katz AE, Siegel DM, Simon M. Myofibroblast phenotype and apoptosis in keloid and palmar fibroblasts in vitro. Cell Death Differ 2000; 7(2):166-76. http://dx.doi.org/10.1038/ sj.cdd. 4400605

4. Luo S, Benathan M, Raffoul W, Panizzon RG, Egloff DV. Abnormal balance between proliferation and apoptotic cell death in fibroblasts derived from keloid lesions. Plast Reconstr Surg 2001; 107(1):87-96. http:// dx.doi.org/10.1097/00006534-20010100000014

5. Akasaka Y, Fujita K, Ishikawa Y, Asuwa N, Inuzuka $\mathrm{K}$, Ishihara $\mathrm{M}$, et al. Detection of apoptosis in keloids and a comparative study on apoptosisbetween keloids, hypertrophic scars, normal healed flat scars, and dermatofibroma. Wound Repair Regen 2001; 9(6):501-6. http://dx.doi.org/10.1046/j.1524475x.2001.00501.x

6. Sandulache VC, Parekh A, Li-Korotky H, Dohar JE, Hebda PA. Prostaglandin E2 inhibition of keloid fibroblast migration, contraction, and transforming growth factor (TGF)-beta1-induced collagen synthesis. Wound Repair Regen 2007; 15(1):12233. http://dx.doi.org/10.1111/j.1524475X.2006.00193.X
7. Gurtner GC, Werner S, Barrandon Y, Longaker MT. Wound repair and regeneration. Nature 2008; 453(7193):314-21. http://dx.doi. org/10.1038/nature07039

8. Zhang Q, Yamaza T, Kelly AP, Shi S, Wang $\mathrm{S}$, Brown $\mathrm{J}$, et al. Tumor-like stem cells derived from human keloid are governed by the inflammatory niche driven by IL-17/IL-6 axis. PLoS ONE 2009; 4(11):e7798. http:// dx.doi.org/ 10.1371/journal.pone.0007798

9. Pakyari M, Farrokhi A, Maharlooei MK, Ghahary A. Critical role of transforming growth factor beta in different phases of wound healing. Adv Wound Care 2013; 2(5):215-24. http://dx.doi.org/10.1089/wound.2012.0406

10. Sato M. Upregulation of the Wnt/beta-catenin pathway induced by transforming growth factor-beta in hypertrophic scars and keloids. Acta Derm Venereol 2006; 86:300-7. http:// dx.doi.org/10.2340/00015555-0101

11. Igota $\mathrm{S}$, Tosa $\mathrm{M}$, Murakami $\mathrm{M}$, Egawa $\mathrm{S}$, Shimizu H, Hyakusoku $\mathrm{H}$, et al. Identification and characterization of Wnt signaling pathway in keloid pathogenesis. Int J Med Sci 2013; 10(4):344-54. http://dx.doi.org/10.7150/ ijms. 5349

12. Lee WJ, Park JH, Shin JU, Noh H, Lew DH, Yang WI, et al. Endothelial-to-mesenchymal transition induced by Wnt $3 \mathrm{a}$ in keloid pathogenesis. Wound Repair Regen 2015; 23(3):435-42. http://dx.doi.org/10.1111/ wrr. 12300

13. Raiskup F, Solomon A, Landau D, Ilsar M, Frucht-Pery J. Mitomycin C for pterygium: long term evaluation. Br J Ophthalmol 2004; 88(11):1425-8. http://dx.doi.org/10.1136/bjo.2003.039891

14. Van Setten G, Aspiotis M, Blalock TD, Grotendorst G, Schultz G. Connective tissue growth factor in pterygium: simultaneous presence with vascular endothelial growth factor-possible contributing factor to conjunctival scarring. Graefes Arch Clin 
Exp Ophthalmol 2003; 241(2):135-9. http:// dx.doi.org/10.1007/s00417-002-0589-1

15. Talmi YP, Orenstein A, Wolf M, Kronenberg J. Use of mitomycin $\mathrm{C}$ for treatment of keloid: a preliminary report. Otolaryngol Head Neck Surg 2005; 132(4): 598-601. http://dx.doi.org/10.1016/j.otohns. 2004.09.060

16. Bailey JN, Waite AE, Clayton WJ, Rustin MH. Application of topical mitomycin $\mathrm{C}$ to the base of shave-removed keloid scars to prevent their recurrence. Br J Dermatol 2007; 156(4):682-6. http://dx.doi.org/10.1111/ j.1365-2133.2006.07714.x

17. Wang YW, Ren JH, Xia K, Wang SH, Yin $\mathrm{TF}$, Xie DH, et al. Effect of mitomycin on normal dermal fibroblast and HaCat cell: an in vitro study. J Zhejiang Univ Scie B 2012; 13(12):997-1005. http://dx.doi.org/10.1631/ jzus.B1200055

18. Taskiran D, Taskiran E, Yercan H, Kutay FZ. Quantification of total collagen in rabit tendon by the Sirius Red Methods. Tr J Med Science 1999; (29):7-9.

19. Liang CC, Park AY, Guan JL. In vitro scratch assay: a convenient and inexpensive method for analysis of cell migration in vitro. Nat Protoc 2007; 2(2):329-33. http://dx.doi.org/10.1038/nprot.2007.30

20. Bijlard E, Steltenpool S, Niessen FB. Intralesional 5-fluorouracil in keloid treatment: a systematic review. Acta Derm Venereol 2015; 95(7):778-82. http://dx.doi.org/10.2340/00015555-2106

21. Payapvipapong K, Niumpradit N, Piriyanand C, Buranaphalin S, Nakakes A. The treatment of keloids and hypertrophic scars with intralesional bleomycin in skin of color. $\mathrm{J}$ Cosmet Dermatol 2015; 14(1):83-90. http:// dx.doi.org/10.1111/jocd.12132

22. Stewart CE, Kim JY. Application of mitomycin-C for head and neck keloids. Otolaryngol Head Neck Surg 2006; 135(6):946-50.http://dx.doi.org/10.1016/j. otohns.2005.07.026

23. Khan MA, Bashir MM, Khan FA. Intralesional triamcinolone alone and in combination with 5-fluorouracil for the treatment of Keloid and Hypertrophic scars. J Pak Med Assoc 2014; 64(9):1003-7.

24. Yeh FL, Shen HD, Tai HY. Decreased production of MCP-1 and MMP-2 by keloid-derived fibroblasts. Burns 2009; 35(3):348-51. http://dx.doi.org/ 10.1016/j. burns.2008.06.018

25. Astashkina A, Mann B. Grainger DW. A critical evaluation of in vitro cell culture models for high-throughput drug screening and toxicity. Pharmacol Ther 2012; 134(1):82-106. http://dx.doi.org/10.1016/j. pharmthera.2012.01.001 